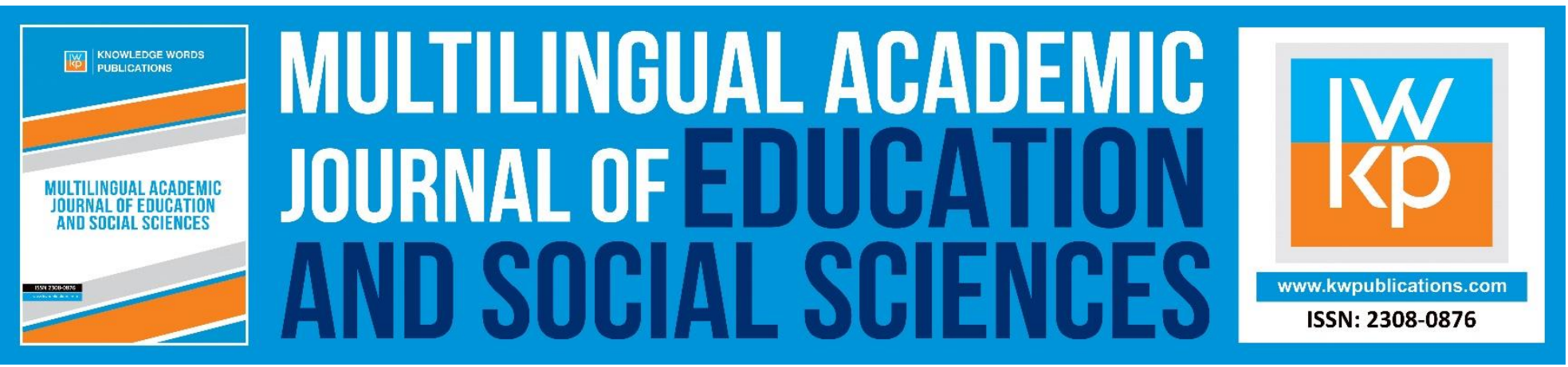

\title{
Fostering Critical Thinking Skills in Preschool Education: Designing, Implementing and Assessing a Multiliteracies- Oriented Program Based on Intercultural Tales
}

Isaak Papadopoulos \& Effrosyni Bisiri

To Link this Article: http://dx.doi.org/10.46886/MAJESS/v8-i1/7263

DOI: 10.46886/MAJESS/v8-i1/7263

Received: 03 March 2020, Revised: 10 April 2020, Accepted: 17 May 2020

Published Online: 25 June 2020

In-Text Citation: (Papadopoulos \& Bisiri, 2020)

To Cite this Article: Papadopoulos, I., \& Bisiri, E. (2020). Fostering Critical Thinking Skills in Preschool Education: Designing, Implementing and Assessing a Multiliteracies-Oriented Program Based on Intercultural Tales. Multilingual Academic Journal of Education and Social Sciences, 8(1), 87-105.

\section{Copyright: (c) The Authors 2020}

Published by Knowledge Words Publications (www.kwpublications.com)

This article is published under the Creative Commons Attribution (CC BY 4.0) license. Anyone may reproduce, distribute, translate and create derivative works of this article (for both commercial and non-commercial purposes), subject to full attribution to the original publication and authors. The full terms of this license may be seen at: $\underline{\text { http://creativecommons.org/licences/by/4.0/legalcode }}$

Vol. 8, No. 1, 2020, Pg. 87 - 105

https://kwpublications.com/journals/journaldetail/MAJESS

JOURNAL HOMEPAGE

Full Terms \& Conditions of access and use can be found at https://kwpublications.com/pages/detail/publication-ethics 


\title{
Fostering Critical Thinking Skills in Preschool Education: Designing, Implementing and Assessing a Multiliteracies-Oriented Program Based on Intercultural Tales
}

\author{
Isaak Papadopoulos \\ European University Cyprus, Cyprus \\ Effrosyni Bisiri \\ Hellenic Open University, Greece
}

\begin{abstract}
This paper outlines a pedagogical programme that aimed at developing critical thinking skills of very young learners. More specifically, an educational programme was designed and implemented within the context of the preschool education, in a school of Larissa during the school year 2018-2019. The programme lasted for seven months and it was applied to 25 children. Following the principles of multiliteracies pedagogy, various activities were implemented towards developing critical thinking skills to children, as they are prioritized as important assets for the citizens of the 21st century. Folk stories, fairytales and games constituted the basic tools employed by the teachers throughout the programme which was carried out through three phases of implementation. In order to evaluate the effectiveness of the programme, the researchers made use of a) journals in every session of the programme and b) portfolios of each child individually. Through the qualitative analysis of the data, it was shown that the children exhibited an increased level of critical thinking while they developed creative and communicative aspects of their behavior while coming into contact with other-culture elements.
\end{abstract}

Keywords: Critical Thinking, Multiliteracies Pedagogy, Preschool, Young Learners, Greece.

\section{Critical Thinking}

Critical thinking has been placed at the center of the research and teaching activity over the last decades while the Council of Europe has issued official documents underlining the importance of enhancing critical thinking skills even from an early age (European Council, 2016). According to Scriven \& Paul (2007, p. 1), critical thinking is "the intellectually disciplined process of actively 
MULTILINGUAL ACADEMIC JOURNAL OF EDUCATION AND SOCIAL SCIENCES

Vol. 8 No. 1, 2020, E-ISSN: 2308-0876 @ 2020 KWP

and skillfully conceptualizing, applying, analyzing, synthesizing, and/or evaluating information gathered from, or generated by, observation, experience, reflection, reasoning, or communication, as a guide to belief and action" (Scriven \& Paul, 2007, p. 1).

Especially, when placing critical thinking within a classroom, it is worth mentioning that it is a mental habit which leads students to reflect on their way of thinking and their views and to investigate multiple and different perspectives in their attempt to improve their understanding (Scriven \& Paul, 2007; Schafersman, 1991; Templeaar, 2006). As it is obvious critical thinking consists of a complex set of interrelated skills which are considered to be important in terms of facilitating individuals "to deal effectively with social, scientific, and practical problems" (Shakirova, 2007, p. 42).

Moreover, as critical thinking is not an innate ability, students need to practice reasoning and apply their critical thinking ability to any field or content area needed (Lundquist, 1999). Within this context, the students need to be motivated to question, examine and explore multiple perspectives from what they come in touch (Papadopoulos \& Griva, 2017). In other words, the students develop important critical thinking skills, when they evaluate not only "what" is conveyed but also the "how" it is constructed and communicated, with the purpose to 'uncover' ideas, to pose disagreements and reconstruct representations (Gainer, 2010).

This context and way of working and thinking appears to contribute to the development of collaborative tendencies of the students. These in turn, are empowered and equipped with such competencies that allow them to better manage complex issues, which necessitate and call for different kinds of expertise (Murnane \& Levy, 1996). However, as it is obvious, such strategies and competencies cannot be easily developed following a traditional approach of instruction. Thus, apart from the importance of developing critical thinking skills, alternative and modern ways of teaching and guiding students are necessary.

Research has shown that lecturing and memorization cannot help towards shaping critical thinkers at schools (Duplass \& Ziedler, 2002; Wong, 2007). Instead, multimodal teaching environments can contribute to the development of critical thinking skills. In particular, the students are provided with multiple representations of information and they can consider the linguistic and visual choices and the purposes they have. They are engaged in situations that can help them to understand or/and experiment in meaning making through using different modes (Archer, 2011; Jewitt \& Kress, 2003).

\section{Multimodality and Pedagogy of Multiliteracies}

The multiplicity of channels of communication including the instruments of meaning- making and the cultural and linguistic differences due to globalisation necessitate a different approach to education (New London Group, 1996, p.60). Greek preschools are multicultural spaces where games, stories and voices are shared among the children in a continuous attempt to learn, to play and to know each other. This linguistic and cultural diversity that exists in the Greek education sector intensifies the need for a modern pedagogical approach which can accommodate multiple needs and learning styles.

Traditional approaches to education emphasized passive learners who strictly abided by rules without posing questions or reasoning about the world (Kalantzis et al., 2003, p.23) thus becoming 'agents of reproduction of received, sanctioned and authoritative representational forms' (Cope \& Kalantzis, 2009, p.175). However, the mission of education nowadays is to create 
MULTILINGUAL ACADEMIC JOURNAL OF EDUCATION AND SOCIAL SCIENCES

Vol. 8 No. 1, 2020, E-ISSN: 2308-0876 @ 2020 KWP

active, flexible, collaborative learners who pose questions about the world, attempt to find solutions to problems, negotiate and collaborate (Kalantzis et al., 2003, p.23). In other words, the major mission of the education of the 21st century requires critical and creative individuals, able to "read" beyond the words (Griva \& Papadopoulos, 2017).

Towards that goal, the pedagogy of 'multiliteracies' overpowers the restrictions of traditional approaches by highlighting the negotiation of various linguistic and cultural differences in the modern society, having short- and long term-impact on students' lives (New London Group, 1996). Multiliteracies promote a behavior of transformation the knowledge and the information acquired, rather than a behavior of reproduction' (Cope \& Kalantzis, 2009). Multiliteracies make reference to the capacity to develop the necessary skills to decipher and formulate meaning accessed by various types of multimodal texts related to technology in multidimensional contexts (Ajayi, 2011, p.398). Having overcome the traditional context of literacy, referring to the ability to read and write, educators should implement multiliteracies pedagogy and view literacy as a means of rendering learners as active designers of meaningmaking in the learning process 'with a sensibility open to differences, change and innovation' (Cope \& Kalantzis, 2009, p.175).

\section{Research on Multiliteracies}

Successful implementation of multiliteracies in the classroom depends on the active roles of both teachers and learners as instruments of design and social change in a multimodal environment (New London Group, 1996, p.64). As a result, traditional approaches to literacy should be replaced by multiliteracies pedagogy focusing on multimodal and integrative texts (Cope \& Kalantzis, 2009, p.166).

The main role of teachers is to facilitate the learning process and create motivating learning conditions in a multimodal and multicultural environment (New London Group, 1996, p.88). As a consequence, it is essential that the implementation of multiliteracies start from early childhood literacy instruction as an active and dynamic process (Cope \& Kalantzis, 2009). Young learners are accustomed to digital multimedia technologies as they experience multimodal texts at home every day (video games, cartoons, videos, toys) (Ajayi, 2011). As a result, teachers should take into consideration these prior experiences and attempt to transform them into motivating, multimodal-literacy learning materials (Nixon, 2003; Ajayi, 2011).

Since multiliteracies necessitate the learners' active role and engagement in the multimodal and multicultural learning environment of literacy (Cope and Kalantzis, 2006, p.37 in Jacobs, 2013), traditional methods of assessment require to be modified in order to abide by the requirements of the changes and developments in both education and society in the twenty-first century (Kalantzis et al., 2003). The atomistic, non-authentic and disembodied techniques of the first- and second-generation testing techniques of isolated 'discrete points' of language (Bachman, 2000), are unsuccessful in evaluating the learners' multiliterate skills (Jacobs, 2013). For this reason, communicative approaches to teaching and testing have placed more emphasis on alternative methods of assessment and 'assessment for learning' (Grabe \& Jiang, 2014). The main aim of these approaches is informal classroom assessment that attempts to enhance the learners' performance in communicative situations by providing direct interaction and feedback to the learners (ibid). As a result, 'a performative approach to assessment' should be implemented to assess multiliteracies (Callow, 2008 in Jacobs, 2013). The portfolio is a self- 
MULTILINGUAL ACADEMIC JOURNAL OF EDUCATION AND SOCIAL SCIENCES

Vol. 8 No. 1, 2020, E-ISSN: 2308-0876 @ 2020 KWP

assessment method and a 'multidimensional process of collecting evidence that illustrates a student's accomplishments, efforts, and progress over time' (Gillespie et al., 1996, p.487 in Griva \& Kofou, 20018, p.29). For this reason, the main aim of this research is to implement the electronic portfolio as a way of assessing young children's multiliteracies skills (Kalantzis et al., 2003).

Multiliteracies skills include conceiving meaning making through attempting to transform of the social world' (Cope \& Kalantzis, 2009); that is, 'multimodality of contemporary forms of representation' including integrated and mulimodal modes of meaning (Cope \& Kalantzis, 2009, p. 166). Modes of meaning include written language, oral language, visual representation, audio representation, tactile representation, gestural representation, and spatial representation (Cope \& Kalantzis, 2009, pp. 178-179). The learners' use of multimodal modes of meaning and multiliteracies skills should be assessed through e-portfolio.

The main aim is to support the learners in the process of becoming active meaning makers and engaged learners in procedures of dealing with multimodal texts, through reading and writing processes, which integrate different modes of presentation (Cope \& Kalantzis, 2009).

\section{The Pedagogical Program}

\section{Rationale and Objectives of the Program}

Having considered the importance of enhancing students' critical thinking skills, we decided to design and implement an educational programme with the purpose to develop critical thinking skills to children of preschool education within a multimodal teaching and learning environment through the children's participation in creative game-based activities that were based on intercultural folk-tales. As a result, the implementation of this programme had the aim to Develop children's critical thinking skills by being exposed to and dealing with a great variety of intercultural folk-tales and by being engaged in multimodal critical activities;

\section{Sample}

The sample consisted of 25 preschoolers from a preschool in Larissa-Central Greece. All the children were of a Greek origin and they were 5 years old. $48 \%$ of the children were boys while $52 \%$ of them were girls (Graph 1).

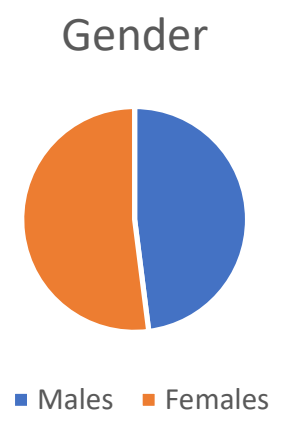

Graph 1. Sample distribution on the basis of the gender 
MULTILINGUAL ACADEMIC JOURNAL OF EDUCATION AND SOCIAL SCIENCES

Vol. 8 No. 1, 2020, E-ISSN: 2308-0876 @ 2020 KWP

\section{Design of the Project}

For the purpose of the programme, a mini syllabus was designed, centered around intercultural folk-tales, incorporating multiple creative activities that fostered a more critical stance and behavior of the children. In this framework, the expected learning outcomes were related to enhancing children's:

- Critical Thinking skills, by being engaged in activities that motivated them to activate behaviors of analyzing, interpreting and evaluating information related to thematic areas of the thematic areas

- Social skills, by encouraging students to participate in collaborative activities with the other preschoolers and to communicate and exchange views and ideas.

- Multicultural sensitivity, by exposing students to aspects of culture of other countries promoting customs, traditions and special features.

Folk-tales were chosen as a basic educational tool for this particular programme as tales are an integral part of the preschool education. Moreover, the researchers decided to make use of folktales young learners are not familiar with such stories and it was the researchers' view that the children could develop more critical tendencies and actions when coming into contact with something not known to them. Besides, the effectiveness of teaching use of folk-tales has been also revealed in other studies conducted in Greece with preschool children, and aimed at developing their language and communication skills

The intercultural folk-tales which were used, were the following:

\section{Greece, "John and the Fairy"}

The Greek folk-tale is related to ambition of a Greek boy called John to marry a fairy, which was considered to be unusual for a human. He followed the advice of an old wise woman, according to who he needed to catch the fairy, he got married to her until she manages to leave during a festival of the village they used to live.

\section{Albania, "Why the mosquito bzzz?"}

This Albanian folk-story is about mosquito and explains according to the Albanian tradition the research that mosquito says bzzz. The mosquito was asked by the lion to bit all the animals in an attempt to find who has the best type of blookd. The mosquito bit a lot of animals without being able to find what the lion has asked, so he bit a human as well, realising that the human has the best blood. Returning back to the lion, another insect hit the mosquito and cut his tongue. Since then, the mosquito does only bzzz.

\section{Cyprus, "Spanos and the water of Dragons"}

Once upon a time there lived a man who was called Spanos and whom everyone considered smart and strong. His village, meanwhile, was plagued by severe water shortages. The villagers needed water to drink, to cook as well as to wash, clean their houses and water their orchards. One afternoon, the villagers begged Spanos to kill the 40 dragons that did not let the water run from the village spring. And Spanos did that. He took the road to find the dragons and after going through many trials, he defeated them. Whatever he did, however, he certainly did with his mind! 
MULTILINGUAL ACADEMIC JOURNAL OF EDUCATION AND SOCIAL SCIENCES

Vol. 8 No. 1, 2020, E-ISSN: 2308-0876 @ 2020 KWP

\section{Serbia, "The king with the sheep ears"}

In this Serbian folk-story, the king of Serbia wanted to have his hair cut and he called several hairdressers to help him. The problem is that this king had very big ears and every hairdresser laughed at him and the king killed them. Only one hairdresser managed to cut the hair of the king without laughing at him with the view of his ears. When the hairdresser finished that, he went and he dug on earth and shouted the secret of the king's big ears. However, high trees grew up there and people used the branches to create flutes. Every time the people played music with the branches they sang, "the king has big ears". The rumor expanded everywhere and the king angrily ordered to kill the young hairdresser. When the hair-dresser explained what happened, the king got so much happy and smiled.

\section{Bulgaria, "The Samodiva and the Shepherd"}

This Bulgarian folk-story refers to the wish of a Bulgarian young boy named Ivaylo to marry a Samodiva that were beautiful creatures. Ivaylo hearing that such a creature was swimming in the river, he went there, he got the grown of her and he prevented her from leaving. However, during a festival of the village, Samodiva persuaded Ivaylo to give the grown back to her to go to the festival and in this way, she escaped.

\section{Romania, "Prostia omenească/The Human Foolishness"}

This story of Romania refers to the attempt of a human to find anyone who is sillier than his family. He noticed a lot of people sillier than him and his family and he realised that different people have different views. For example, he saw a person who tried to capture sunlight in a bucket instead of making a window for his house or someone who attempts to get his cow to climb the ladder to be fed rather than take the fodder down from the barn.

\section{North Macedonia, "The son who loved a coffin"}

This folk-story refers to a strange love relationship between a Prince and a dead girl. When a prince discovered a coffin with a dead girl and he decided to hide it in a secret room in the castle. Just before the prince left for a fight, he asked his mother not to open the room that he had placed the dead girl. However, his mother was so curious, opened the door and went into the room. She saw the dead girl and was fascinated by her beauty. So she took a scarf, soaked it with wine, and covered the girl's face with it. In this way, the girl came to life. When the prince returned to the castle, he realised that the coffin was not there and got really angry at her mother. However, the surprise was the girl was waiting for him and he got married.

\section{Croatia, "The fisherman and his wife"}

The Croatian story is about a fisherman who caught a fish in the sea. It could speak and asked the man to let it be free. To thank him, it would help the man in every wish he had. The fisherman put it in the sea but when he returned home, he informed his wife about that. She made him ask for many things like money, jewelleries and comforts. In the end, she asked to be the God of the World, but the fish was really angry at the woman and it took all the comforts it had offered to that family. 
MULTILINGUAL ACADEMIC JOURNAL OF EDUCATION AND SOCIAL SCIENCES

Vol. 8 No. 1, 2020, E-ISSN: 2308-0876 @ 2020 KWP

\section{Implementation Procedures}

This particular program was designed and implemented following the principles of the Multiliteracies Pedagogy. On condition that the pedagogy of Multiliteracies places emphasis on the changeable ways of constructing meaning in multifarious 'cultural, social or domain-specific' backgrounds (Cope \& Kalantzis, 2015, p.3), educators of literacy are dictated to view literacy as a way of communicating' which includes effective communication in diverse environment as well as the use of multimodal tools that can facilitate students' activities (Kalantzis et al., 2003). In the multiliteracies pedagogy, leaners expand their 'critical language awareness', communication abilities through taking advantage of their personal, textual, cultural and social experiences in the learning process (Griva et al., 2018, p.35), thus being qualified 'to negotiate differences in patterns of meaning from one context to another' (Cope \& Kalantzis, 2015, p.3). Literacy as defined by traditional approaches includes 'sentence-bound rules of spelling and grammar' (Kalantzis et al., 2003, p.22). As a consequence, literacy in this way has to be altered in order to adapt to the new modes of communication including the instruments of meaning-making. The pedagogy of Multiliteracies suggests transformative ways of knowing, the four 'knowledge processes': 'experiencing, conceptualizing, analyzing and applying' (Kalantzis \& Cope, 2004, p.64). These knowledge processes serve as an outline to be followed by educators about their educational and pedagogical actions and objectives (Cope \& Kalantzis, 2009, p.186).

Each folk-tale was a different thematic unit that was designed around the abovementioned knowledge processes, and lasted for 2 to 3 weeks of implementation during the school year 2018-2019. More specifically, the program was carried out as follows:

\section{Experiencing}

The knowledge process of experiencing is related to learning through the person's engagement in daily events, which lead him/her to come into contact with facts, data and evidence of the world (Cope \& Kalantzis, 2015). Experiencing the known refers to a multidimensional set of action of the people, who reflect on their experiences, their points of view and the matters of their interest along with the ways of expressions and understanding (Cope \& Kalantzis, 2009). Experiencing the New refers to the learner's immersion in a situation not familiar to him/her, either through live contact or virtually (Cope \& Kalantzis, 2015).

\section{A. Experiencing the known}

Task A: The teacher shows the learners a promotion video on several known farytales and encourage the learners to find the fairytales' titles, choose their favourite one and discuss it in class.

\section{B. Experiencing the new}

Task B: The students are provided with templates of a person-pattern in a small piece of paper as assigned homework and they have to paint it themselves. The teacher makes different crafts like, a hot-air-balloon, a train, a car (thematic areas known to the young children) and stick each time the learners' drawings around the craft. The teacher also makes a drawing of him/herself). The teacher places a large map of the world on the floor. He/She asks the learners to sit around the map. He/She says: "Welcome to the magical world of fairytales. We are setting off a journey around the world in order to listen to stories from around the world and from different cultures. 
MULTILINGUAL ACADEMIC JOURNAL OF EDUCATION AND SOCIAL SCIENCES

Vol. 8 No. 1, 2020, E-ISSN: 2308-0876 @ 2020 KWP

Where would you like to go? Which country? Let's see..." The teacher moves the hot-airballoon/car/etc... around the map and places it on the country he/she focuses on.

Task C: The teacher shows the learners pictures of things related to the country of the tale and ask them if they know the country, where it is on the map, whether they know about fairytales of the country. Moreover, the teacher shows them a video about the country and asks them what they like most about the country, underlining that the country has interesting tales for them.

Task D: The teacher asks learners express their views about some pictures related to the tale. As they are preschooler and they cannot read, the students are asked to describe the pictures in the teacher's attempt to investigate whether they are familiar with these concepts. Based on these words, the teacher asks the learners to predict what the story they are going to deal with is about.

Task E: The teacher shows the learners the first minutes of the story of the tale (or reads the very first part of the story) and invite the learners to guess and predict what happens in the story. They express themselves freely and creatively.

\section{Conceptualizing}

Conceptualizing refers to the development of abstract concepts and to a theoretical synthesis of the concepts that individuals come into contact with (Cope \& Kalantzis, 2015, p.19). 'Conceptualizing by naming' implies the person's actions towards seeking for and finding similarities and differentiations, towards categorizing items and naming them (Cope \& Kalantzis, 2009 , p. 185). Moreover, 'conceptualizing with theory' refers to linking concepts into a language of generalizations, or seeing the concepts from a wider perspective, highlighting the semantic relations of concepts that can be represented in multimodal forms (Cope \& Kalantzis, 2015, p.20).

\section{Conceptualizing by Naming}

Task F: The teacher divides the learners into small groups. He/She shows the whole story of the folk-tale and asks them to draw the main characters on the painting sheet they have. Each group get prepared to present a hero of the story along with the teacher. They explain the colours they made use of, the way they draw the heroes, the reason they believe that they are the protagonists and the importance of their role in the story.

\section{Conceptualizing with Theory}

Task G: The teacher invites the learners who are already in groups to categorize the main characters into heroes and villains on their drawings and discuss their views all together. Within the context of this activity, the learners need to think critically so that they can choose, categorise the heroes, justify their answers and choices with arguments they have to present. The teacher tries to facilitate the learners' attempts by encouraging them to keep symbolic notes, like symbols, points, small drawings, so that they can remember and have a guide.

\section{Analysing}

Analyzing is a knowledge process, which refers to the person's actions towards examining the cause and effect, the form and the functionality as well as the relationships of items. As it is 
MULTILINGUAL ACADEMIC JOURNAL OF EDUCATION AND SOCIAL SCIENCES

Vol. 8 No. 1, 2020, E-ISSN: 2308-0876 @ 2020 KWP

implied, analyzing calls for employing reasoning with the purpose to explain something and achieve argumentation purposes (Cope \& Kalantzis, 2015). More specifically, when analysing functionally, a person is engaged in reasoning procedures, making inferential and deductive conclusions. In this way, relationships like cause/effect are established and logical analysis is achieved (Cope \& Kalantzis, 2009). Last, when analysing critically, people tend to evaluate different peoples' perspectives, their motivates and their purposes, which is go beyond functionality (Cope \& Kalantzis, 2009, p. 186).

\section{E. Analysing Functionally}

Task H: The teacher asks the learners to watch the folk-story and in a second phase to place the pictures that he distributed to them, in the correct order so that they can have a complete story. The learners are encouraged to collaborate, exchange views on the correct order, discuss their ideas and their beliefs about the story scenes etc.

\section{F. Analysing Critically}

Task I: The teacher divides the learners into small groups and asks them to try to explain the behaviour of two heroes. The learners need to choose two heroes, describe their behaviour and actions and express their view on them. The other learners ask questions, comment on what their classmate has said and they try to ask for more information.

\section{Applying}

Applying is a Knowledge Process which underlines the application of experiential, conceptual and critical knowledge acquired by people, who tend to be engaged in the world being equipped with such tools of knowing something of the world and offer their knowledge to it (Cope \& Kalantzis, 2015). Applying appropriately refers to applying knowledge and understandings within the context of diverse world situations and testing their validity (Cope \& Kalantzis, 2009). In parallel, applying creatively is related to people's intervention in the world by bringing or having innovative and creative practices, which are of learners' personal interests, related to their experiences and aspirations (Cope \& Kalantzis, 2009, p. 186).

\section{G. Applying Appropriately}

Task J: The teacher shows the learners four pictures that are different scenes in the story. The learners are divided into group and each group is asked to choose one and draw both the priorscene and the post-scene of the one they already have. The teacher saves all the drawings and in a following session asks the learners to present their drawings and describe them to the whole class.

\section{H. Applying Creatively}

Task K: The teacher asks the learners to retell the story of each country. He/she helps them to stand in the correct order according to their drawings and the chronological order in the story. Before they start they have to rehearse their presentation along with the teacher.

Task L: The teacher asks the learners to create a drawing related to their thoughts about the tale and the country they dealt with. They present their thoughts to the other classmates and discuss all together. 
MULTILINGUAL ACADEMIC JOURNAL OF EDUCATION AND SOCIAL SCIENCES

Vol. 8 No. 1, 2020, E-ISSN: 2308-0876 @ 2020 KWP

\section{Evaluation \& Results of the Programme}

In order to evaluate the efficacy of this programme, the researchers made use of two research instruments while the data gathered were analysed qualitatively and quantitatively.

\section{Research Instrument 1. Journal of the Researchers}

First of all, journals were kept by the teacher/researcher in every teaching session throughout the programme. Concerning the form of the journal, its structure was based on the "questions for journal keeping" of Richards \& Lockhart (1994). The questions of the journals were set by the teacher/researcher and they focused on three fields: a) questions about instruction (1. What objectives did I set? To what extend did I achieve them?, 2. What teaching material did I use? How effective were the teaching aids? And 3. What forms of communication among students and the teacher were used?), b) questions about students" attitude and participation (1. Which was the students" attitude at the beginning, middle and at the end of each activity? How did I react?) and c) questions about the general estimation of the instruction (1) What went well and what did not? Why? And 2) What could I change? Why?)

\section{Findings derived from the journal keeping}

The journal notes facilitated the analysis of the children's critical profile empowerment, through their participating in this educational programme. More specifically, the notes kept by the researchers through journals led to the creation of three field of findings, related to A) Critical Profile, B) Teaching Techniques/Strategies and C) Ways of Thinking and Working while the corresponding findings were grouped into a)knowledge-based, b)skills-based and c)attitudesbased features of the children.

The following table (Table 1.) presents findings that are related to the Critical Profile of the children as observed through the journal keeping procedures. In particular, through the children's participation in the programme, the researchers noticed that they seemed to be acquiring an understanding of the ways to be used for dealing with familiar issues that derived from the topics of the folk-tales or the cultural elements of each country. The children appeared to be trying to identify gaps in "problematic" situations and generate their skills of critical thinking.

Within this context, the children were observed to analyze parts of a whole, when dealing with "tasks" that had to be carried out. They exhibited an increased ability to identify and examine ideas with purpose to synthesize their spoken discourse when needed. They also employed a basic repertoire of persuasive strategies when discussing and they appeared to be able to differentiate useful and non-useful information. Therefore, they seemed to develop a flexibility and curiosity to uncover and co-construct meaning when needed. 
MULTILINGUAL ACADEMIC JOURNAL OF EDUCATION AND SOCIAL SCIENCES

Vol. 8 No. 1, 2020, E-ISSN: 2308-0876 @ 2020 KWP

Table 1. Critical Profile of Preschoolers

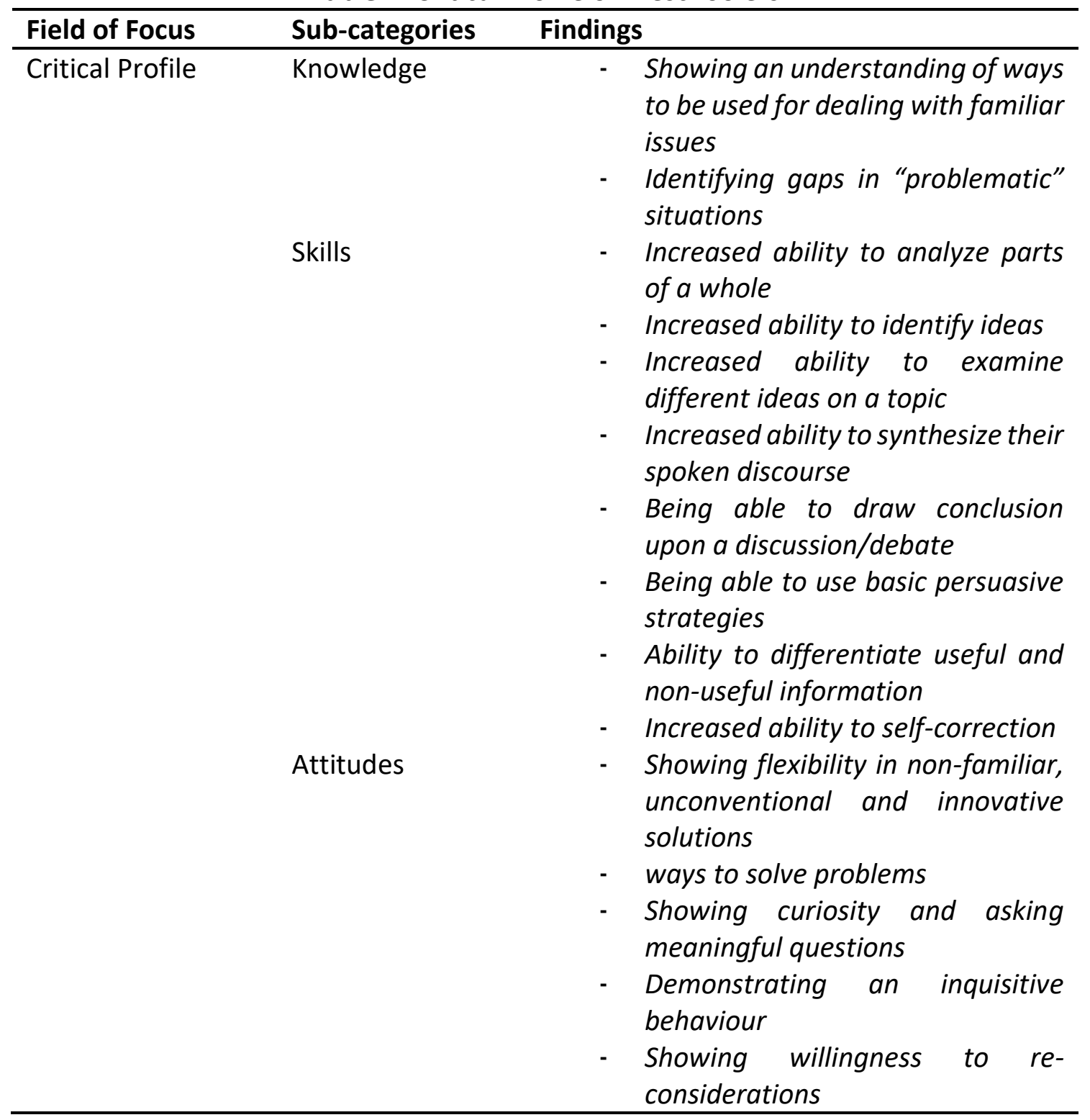

Through the analysis of the journal notes, the researchers searched for percentages of frequency with regard to certain points of the teaching and learning procedures. More specifically, the following table (Table 2) presents that a variety of techniques, activities and aids were used within the context of this particular programme and provided students with opportunities to examine and reflect on certain topics related to folk-tales. The teacher made more use of conversation/discussion (62\%) and brainstorming strategies (61\%) as it is revealed from the investigation of frequency of occurrence of each strategy.

As for the teaching material, in every teaching session folk-tales were used as they constituted the basic educational tool of the programme. There was also use of classical literature tales $(70 \%)$ while the teacher made use of photos $(78 \%)$, videos $(74 \%)$, songs $(67 \%)$ and crafts (55\%). 
MULTILINGUAL ACADEMIC JOURNAL OF EDUCATION AND SOCIAL SCIENCES

Vol. 8 No. 1, 2020, E-ISSN: 2308-0876 @ 2020 KWP

Table 2. Teaching Techniques and Materials

\begin{tabular}{lll}
\hline Field of Focus & Sub-categories & $\begin{array}{l}\text { Findings } \\
\text { Frequency Occurrence) }\end{array}$ \\
\hline Teaching Sessions & Teaching & $62 \%$ - Conversation/Discussion \\
& $61 \%$ - Brainstorming \\
& Techniques/ & $57 \%$ - Group learning \\
Strategies & $51 \%$ - Role-plays \\
& $47 \%$ - Cognitive conflict \\
& $34 \%$ - Concept maps \\
& \\
& $100 \%$ - Folk-tales \\
& $70 \%$ - Classical literature tales \\
& $78 \%$ - Photos \\
& $74 \%$ - Videos \\
& $67 \%$ - Songs/Music \\
& $55 \%$ - Crafts \\
&
\end{tabular}

As for the ways of thinking and working of the children, the following table (Table 3) presents aspects of students' interaction. In particular, the children appeared to exhibit creative ways of thinking and acting through their participating in this educational programme. They seemed to think and work creatively on collaborative tasks which were proved to help their communicative behaviour and skills. They developed attitudes of respect and valuing others and their perspectives and they seemed to be willing to discuss views on various topics related to the tales.

Table 3. Ways of Thinking and Working

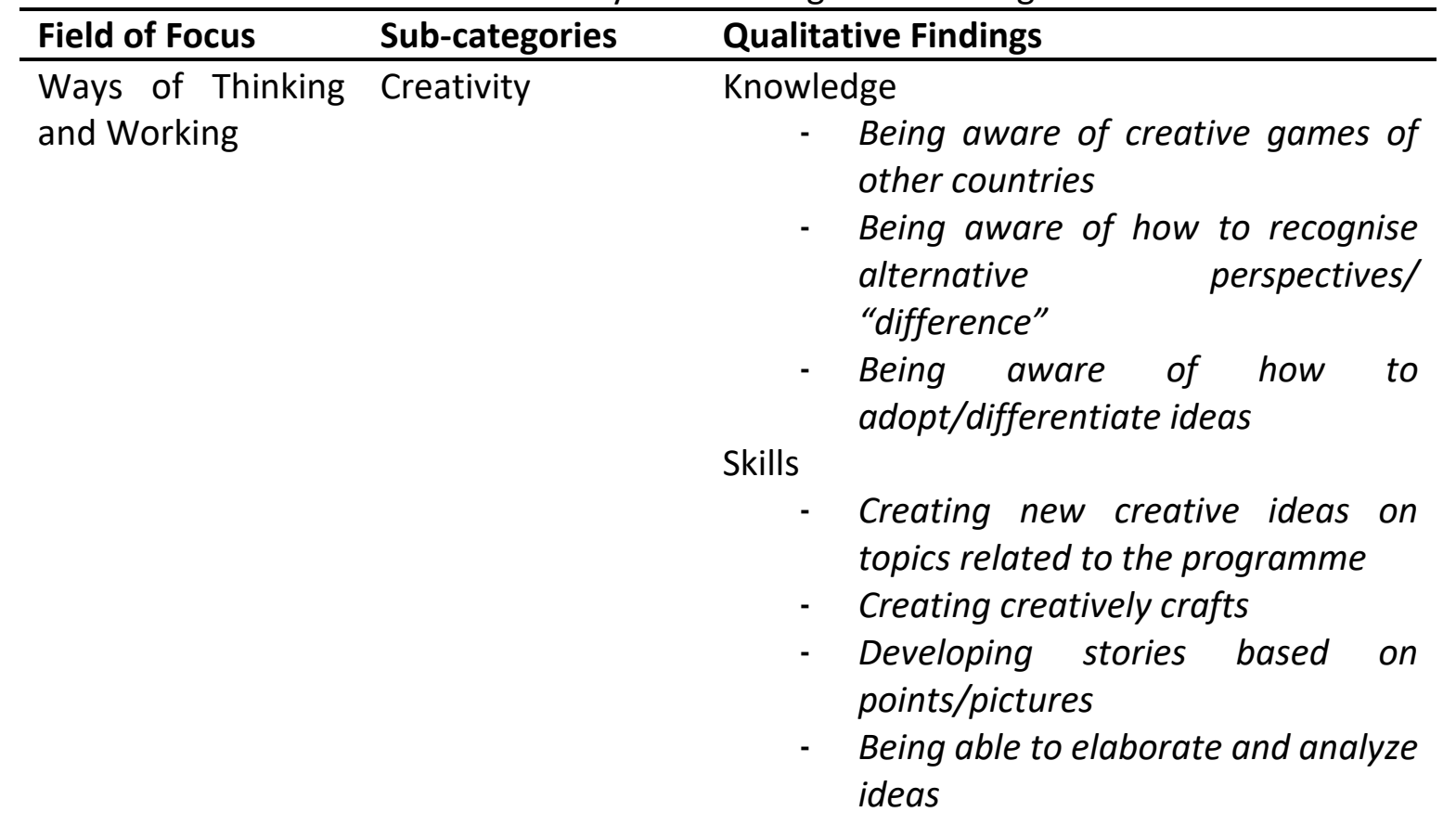




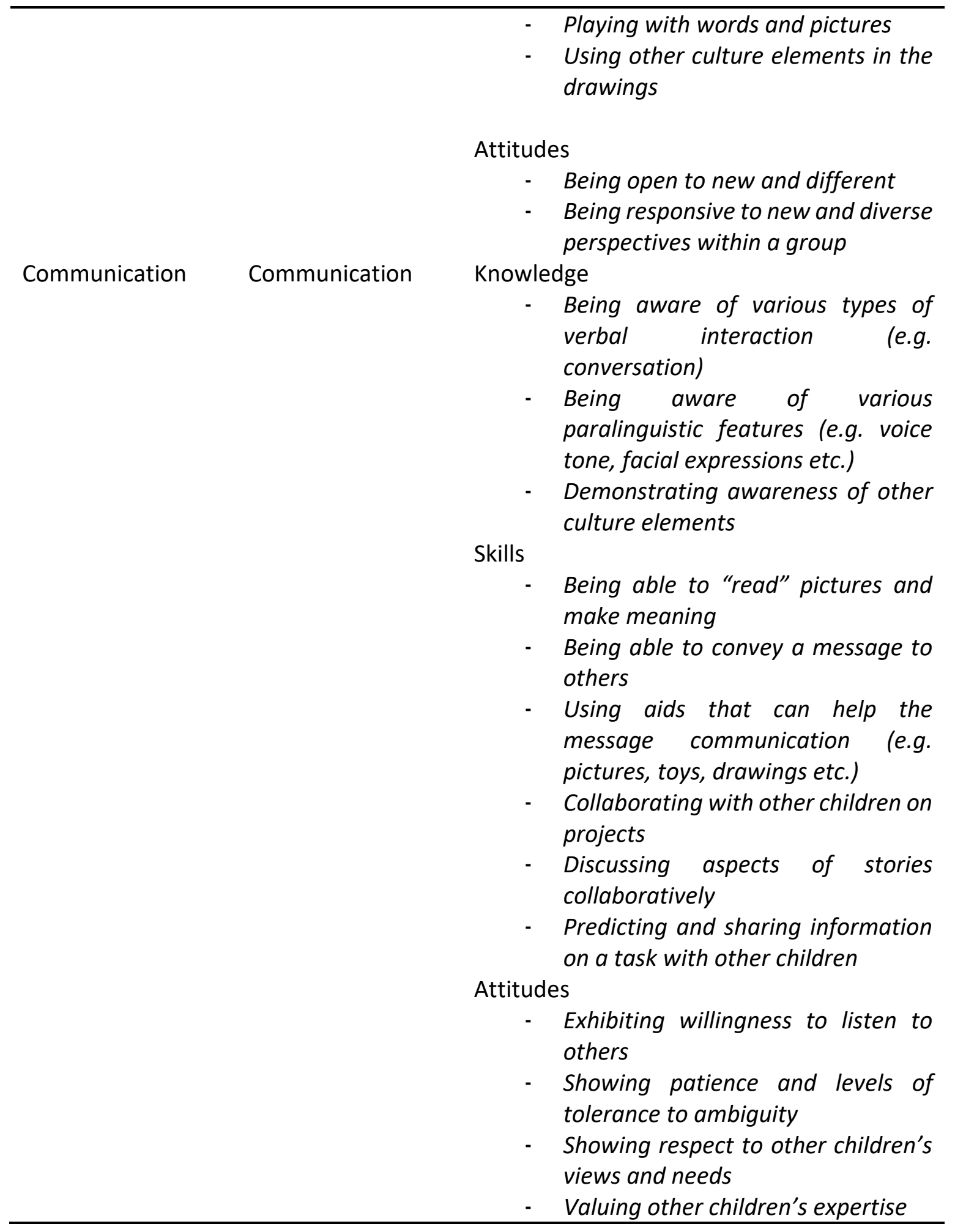

\section{Research Instrument 2. Children's Portfolios}

It is imperative that assessment 'as an interactive process' (Hancock, 1994, p.3) should incorporate alternative methods and 'assessment for learning' (Grabe \& Jiang, 2014, p.8) the emphasis of which is paced on enhancing the learners' performance in communicative situations 
through offering an interactive feedback to the learners (Grabe \& Jiang, 2014, p.8). Portfolio constitutes a method of alternative assessment which encourages the learners and the teachers to monitor the student's performance (Hancock, 1994). Within the context of this study, portfolios of children were also employed as a second research instrument. Portfolios represent an authentic and detailed record of learners' performance (Kalantzis et al., 2011, $\sigma .31$ ).

Portfolio is considered to be a continuous cumulative record of the learners' language enhancement and a holistic view of student learning (O'Malley \& Pierce, 1996). In addition, portfolios report and record not only the learners' writings but also 'unique life experiences and other learning achievements that would enable open sensibilities to be measured as well as the individual strengths of diverse individuals' (Kalantzis et al., 2003, p. 24). Portfolios were employed as they can facilitate the understanding of the children's attempts to demonstrate their progress and improvement (Stiggins, 1994) throughout the programme they were engaged in. According to Griva and Kofou (2018) portfolio is a very important tool of assessment and it goes beyond assessment by promoting an awareness of students' development. The children were invited and encouraged to systematically reflect on their progress and learning and include their work (crafts, posters, drawings etc) after each session of each thematic area of the country.

\section{Findings Derived from the Portfolios Keeping}

Through the analysis of the children's portfolios, it was revealed that the children were critically and creatively engaged in the learning procedures.

Indicatively, Picture 1 refers to an activity in which children were encouraged to seek for similarities and differences between the Greek and Albanian traditional costume. In this way, they had to use the red colour for the differences and the green for similarities, in an attempt to foster critical thinking skills.

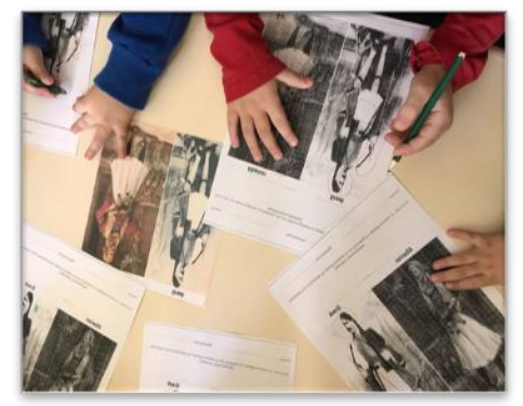

Picture 1. Differences and Similarities

Picture 2 is related to an activity in which the children had to create a craft about Cyprus. In this way, they had to think about the division of Cyprus considering the northern part of Cyprus which has been possessed. They made use of black colour to focus on the pain of the people while they used green colour in the southern part to underline the "happiness" of the people living there. 


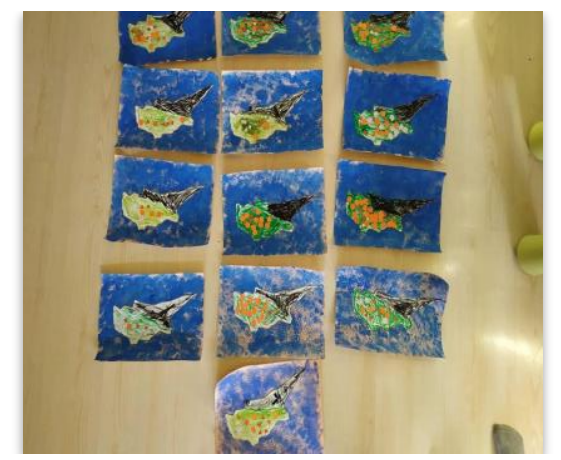

Picture 2. The country of Cyprus

Last, Picture 3 presents creations of children within the context of the thematic are on Serbia. The children acquired an awareness of Serbian painters and the patterns used in their paintings, thus, they experimented in making their own creations.

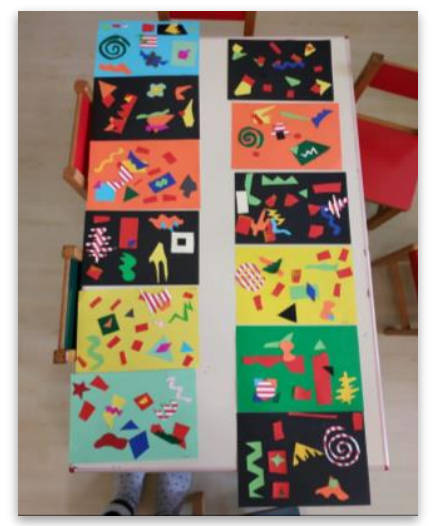

Picture 3. Patterns of Young Painters

\section{Concluding Remarks}

Through this particular pedagogical programme, an attempt was made to foster critical thinking skills to preschoolers in Greece. Meanwhile, we decided to make use of intercultural folk-tales with the purpose to familiarise children with aspects of multiculturalism living in the $21^{\text {st }}$ century. Although it is not scientifically safe to support that students developed high levels of critical thinking skills, it is our conclusion that they enhanced their critical stances and behaviours, empowering some perspectives of critical thinking, which were analysed above.

Through the processing and the analysis of the data, derived from journal keeping and portfolio keeping procedures, it was revealed that the programme provided children with multiple opportunities for critically dealing with information similar to or different from what they knew. The intercultural folk-tales within a multiliteracies-oriented context, facilitated the children's occupation with and introduction to a "different" world of cultures which was accompanied with a great variety of game-based activities or/and activities of creative expression and collaboration in an attempt to decrease the sentimental filter of the children (Bella, 2007).

Moreover, the children seemed to empower their critical stances and competencies in a way that facilitated their learning and the comprehension of the new taught concepts related to each culture. More specifically, they were proved to acquire an awareness of how to deal with 
MULTILINGUAL ACADEMIC JOURNAL OF EDUCATION AND SOCIAL SCIENCES

Vol. 8 No. 1, 2020, E-ISSN: 2308-0876 @ 2020 KWP

issues that they are not familiar with, especially when they participated in activities that were task-oriented and called for more critical behaviour and occupation. Indeed, both the national (Papadopoulos \& Griva, 2017) and the international literature (Haydey, Kostiuk, \& Phillips, 2007; Morgan \& York, 2009), underline that task-based activities motivate more the children and encourage them to think critically and creatively to reach the goal. Towards fostering critical thinking skills, the multimodal teaching and learning environment was very helpful, as the children were provided with multiple representations of information (Haydey et al., 2007). This helped the children as they were urged to seek for differentiations, identify gaps and examine different solutions/ideas.

As for the multimodal learning environment, it was proved to serve beneficially towards the enhancing of creative and communication skills and behaviours of the children. In particular, this wealth of modes in the representation of knowledge, the collaborative tasks and games as well as the "problems" that called for creative solutions, motivated the children to collaborate, exchange views and exhibit respect to others. The children in this way, practice their patience and tolerance towards the others, which are considered to be important features of interculturally competent speakers (Papadopoulos \& Tsitsanou, 2020; Papadopoulos, 2019)

Taking everything into consideration, it was shown that educating young children following a multiliteracies pedagogy can be very important and useful in terms of fostering skills and competencies, which are promoted as features of the $21^{\text {st }}$ century. It is more than necessary preschool teachers to design and implement such project that have an advantageous impact on children.

\section{References}

Archer, A. (2011). Clip-art or Design: Exploring the challenges of multimodal texts for Writing Centres in Higher Education. Southern African Linguistics and Applied Language Studies, 29 (4), 387-399.

Ajayi, L. (2011). A multiliteracies pedagogy: Exploring semiotic possibilities of a Disney video in a third grade diverse classroom. The Urban Review, 43(3), 396-413.

Bachman, L. F. (2000). Modern Language Testing at the Turn of the Century: Assuring that what we Count Counts. Language Testing, 17 (1), 1-42.

Bella, S. (2007). A Second Language: Acquisition and Teaching. Athens: Ellinika Grammata (In

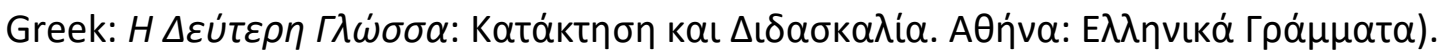

Duplass, J. A., \& Ziedler, D. L. (2002). Critical thinking and logical argument. Social Education, 66(5), 10-14.

Callow, J. (2008). Show me: Principles for assessing students' visual literacy. The Reading Teacher, 61(8), 616-626. doi:10.1598/ RT.61.8.3

Cope, B., \& Kalantzis, M. (2006). From literacy to "multiliteracies": Learning to mean in the new communications environment. English Studies in Africa, 49(1), 23-45. doi:10.1080/ 00138390608691342

Cope, B., \& Kalantzis, M. (2009). Mutliliteracies: New literacies, New learning, Pedagogies: An International Journal, 4, 164-195. 's[epí.

Cope, B., \& Kalantzis, M. (2015). The things you do to know: An introduction to the pedagogy of multiliteracies. In B. Cope \& M. Kalantzis (Eds.), A Pedagogy of Multiliteracies. Learning by Design (pp. 1-37). New York, NY: Palgrave Macmillan. 
MULTILINGUAL ACADEMIC JOURNAL OF EDUCATION AND SOCIAL SCIENCES

Vol. 8 No. 1, 2020, E-ISSN: 2308-0876 @ 2020 KWP

Council of Europe. (2016). Living together as equals in culturally diverse democratic societies. Council of Europe Publishing

Gainer, J. S. (2010). Critical media literacy in middle school: Exploring the politics of representation. Journal of Adolescent \& Adult Literacy 53(5), 364-373.

Gillespie, C., Ford, K., Gillespie, R., \& Leavell, A. (1996). Portfolio assssment: Some questions, some answers, some recommendations. Journal of Adolescent and Adult Literacy, 39, 480491.

Grabe, W., \& Jiang, X. (2014). Assessing Reading. In Kunnan, A. J. (Ed.), The Companion to Language Assessment, First Edition, (pp. 1-16). John Wiley \& Sons, Inc.

Griva, E., \& Kofou, I. (2018). Alternative assessment in Language learning: Challenges and Practices. Kyriakidis Editions.

Griva, E., \& Kofou, I. (2018). Language portfolio serving as a tool for developing/assessing multilingual skills and inter/multicultural competence. Current Topics in Language and Literature - An International Perspective. Cambridge Scholars Publishing.

Griva, E., Maroniti, K., \& Stamou, A. G. (2018). 'Linguistic Diversity on TV': A Program for Developing Children's Multiliteracies Skills. Journal of Language and Education, 4(3), 34-47. doi:10.17323/2411-7390-2018-4-3-34-47.

Hancock, C. R. (1994). 'Alternative Assessment and Second Language Study: What and Why?.' ERIC Digest, 1-17.

Haydey, D. C., Kostiuk, J., \& Phillips, S. (2007). Developing critical literacy for all students. TalentEd, 25(1), 19-25.

Jacobs, G. E. (2013). Designing Assessments A Multiliteracies Approach. Journal of Adolescent \& Adult Literacy, 56(8), 623-626. doi:10.1002/JAAL.189

Jewitt, C., \& Kress, G. (2003). Multimodal literacy. New York: Peter Lang.

Kalantzis, M., \& Cope, B. (2004). Designs for Learning. E-Learning, Volume 1, Number 1, pp.3893.

Kalantzis, M., Cope, B., \& Harvey, A. (2003). Assessing multiliteracies and the new basics. Assessment in Education: Principles, Policy \& Practice, 10 (1), 15-26.

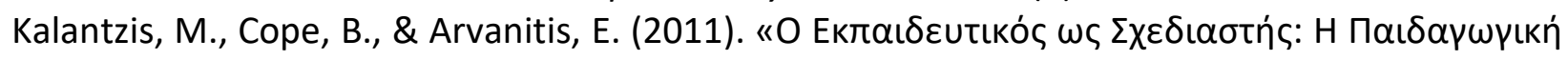

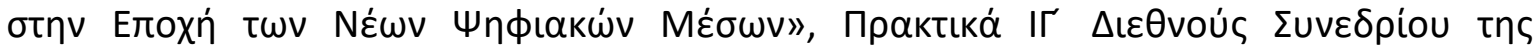

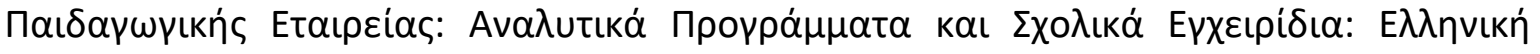

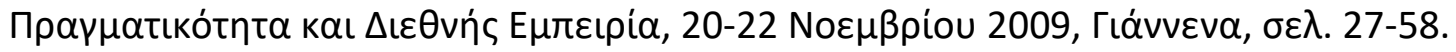

Lundquist, R. (1999). Critical thinking and the art of making good mistakes. Teaching in Higher Education, 4(4), 523-530.

Morgan, H., \& York, K. C. (2009). Examining multiple perspectives with creative think-alouds. The Reading Teacher. 63(4), 307-311.

Murnane, R. J., \& Levy, F. (1996). Teaching the New Basic Skills Principles for Educating Children to Thrive in a Changing Economy. New York Free Press.

New London Group. (1996). A pedagogy of multiliteracies: Designing social futures. Harvard Educational Review, 66(1), 60-92.

Nixon, H. (2003). New research literacies for contemporary research into literacy and new media? Reading Research Quarterly, 38(3), 407-413. is

O’Malley, J. M., \& Pierce, V. L. (1996) Authentic Assessment for English Language Learners: Practical Approaches for Teachers. New York: Longman 
Papadopoulos, Is., \& Griva, E. (2017). Promoting critical literacy in the EFL context: implementing a project to young learners. European Journal of Language and Literature Studies, 7 (1), 107-120.

Papadopoulos, Is. (2019). Shaping the intercultural communicative profile of young foreign language students: a multidimensional analysis of their written discourse. Journal of Linguistics and Intercultural Education. 12 (1), 131-142

Papadopoulos, Is. \& Tsitsanou, Ch. (2020). A melody of young learners' intercultural voices: findings from a transnational study. Published in the Proceedings of the 3rd IECAT - "New Challenges in Education", Drama (Greece), 8-10 May 2020 (in press)

Richards, J. C. and C. Lockhart. (1994). Reflective Teaching in Second Language Classrooms. Cambridge University Press.

Shakirova, D. M. (2007). Technology for the shaping of college students' and upper-grade students' critical thinking. Russian Education \& Society, 49(9), 42-52.

Schafersman, S. D. (1991). An introduction to critical thinking. Retrieved January 2, 2020, from http://www.freeinquiry.com/critical-thinking.html

Scriven, M., \& Paul, R. (2007). Defining critical thinking. The Critical Thinking Community: Foundation for Critical Thinking. Retrieved January 2, 2008,

Stiggins, R. J. (1994). Student-centered classroom assessment. New York: Macmillan Publishing Company.

Tempelaar, D. T. (2006). The role of metacognition in business education. Industry and Higher Education, 20(5), 291-297.

Wong, D. (2007). Beyond control and rationality: Dewey, aesthetics, motivation, and educative experiences. Teachers College Record, 109(1), 192-220. 